\title{
GALICIA, OR THE SPURIOUS CHILD: ILLEGITIMATE ORIGINS IN THE MODERN NOVEL
}

\author{
DANNY M. BARRETO \\ Colgate University
}

Aвstract: The present article uses Suso de Toro's Sete palabras as a starting point for analyzing the protagonism of illegitimate children in the Galician novel since the Rexurdimento. Considered in a historical context and as a literary trope, the illegitimate child can be read as an expression of anxiety around a national identity rested upon a notion of purity, be it linguistic, ethnic or territorial. These unclear origins, rather than preclude the possibility of identity formation and history —individual or collective — can serve as a source for alternative histories and identities.

KEYwords: foundlings, illegitimacy, Rexurdimento, Suso de Toro, identity.

\section{Galicia, ou a filla espúrea: oriXes ilexítimas na nOVEla moderna}

Resumo: Este artigo emprega a novela Sete palabras de Suso de Toro como punto de partida para analizar o protagonismo dos nenos ilexítimos na novela galega dende o Rexurdimento. Examinado no seu contexto histórico e como un tropo literario, o fillo ilexítimo pode entenderse como expresión de ansiedades sobre a identidade nacional baseada nun concepto de pureza lingüística, étnica ou territorial. Estas orixes ilexítimas, en lugar de descartar a posibilidade de xerar unha identidade e unha historia — xa sexan individuais ou colectivas-, teñen o potencial de axudarnos a concibir historias e identidades alternativas.

Palabras chave: expósitos, ilexitimidade, Rexurdimento, Suso de Toro, identidade.

Porque él puede llevar un apellido y decir... jeste soy! porque á él la sociedad le dice...ipasa! pero á mí, no...

Jacobo San Martín, «Lo que envidia un expósito» (I880)

The fragment above narrates an encounter between the poet, an orphan and a foundling, in which the latter expresses his envy of the orphan who at least knows his origins. The intersection of identity, social legitimacy and literature, 
a recurrent element of igth century fiction, appears as a site of tension in Suso de Toro's Sete palabras (2009). The novel invites us to think not only about how a dubious origin requires a questioning of the constitutive elements of Galician identity, but also prompts an analysis of the untold history of foundlings, orphans and illegitimate children. Despite their social invisibility, these were the ubiquitous subjects and protagonists in the narrative fiction of the Rexurdimento. De Toro's novel establishes a connection with this literature, inviting us to rethink illegitimacy as a productive element of Galician identity rather than a source of shame.

Contemporary Galician literature, as Cristina Moreiras-Menor has argued, «supone un espacio ideal para abordar cuestiones de nación, canon literario nacional y sujeto/subjetividad nacional» (20II: I52). Many of these questions arise from the gaps in cultural and historical memory, whether related to war, emigration, exile, gender, language or any other elision in the dominant national narrative. In order to address these, both artists and scholars have been turning to a narrative characterized by «nuevas estrategias que ofrecen - y/o recuperan - reflexiones sobre el pasado y la memoria cultural y las nuevas maneras de leer y narrar la especificidad cultural gallega en el presente» (20 I : I52). Within this context, de Toro's novels have been deemed exemplary for their interrogations of the past and explorations of the rifts within cultural memory and collective identity (Moreiras-Menor 20ıI; Romero 2012; Sánchez 2009, 20II; Gómez-Montero 2012; Richardson 2002). It is through this «función anamnésica» that imbues his writing, Javier Gómez-Montero claims, that de Toro establishes «la legitimación de la novela contemporánea para reivindicar las memorias aniquiladas» (2012: 42).

Questions of legitimization, literature and memory lie at the center of Sete palabras, an autobiographical novel that leads the reader in pursuit of Faustino, the paternal grandfather of the narrator/author. Faustino left his wife and children to find work in Cuba, disappearing a short time later without trace. When the narrator was growing up, his grandfather's absence was enshrouded in silence, myth and mystery. At the age of 50 , with his grandmother deceased and his father's health severely impaired after a series of strokes, uncovering the history of this man has become the narrator's obsession, feeling that as the third generation of de Toro men it is he «o que ten que cavar» (2009: 33). Critics have focused on the novel's place in de Toro's evolving professional trajectory, considering «el texto hasta ahora más personal de Suso de Toro y en el que él mismo — como persona y escritor — se transfigura en personaje litera- 
rio interpelado en la novela bajo el auspicio de la segunda persona personal» (Gómez-Montero 2012: 57). The author's move away from urban spaces towards the self as a problematic site of memory represents an important variation on a trope in his oeuvre. Yet, the ruptures and absences in that personal history expose the cracks in a collective history and cultural identity.

Few clues are offered by the scant documentation from the late 1800 s in the hospitals and orphanages the narrator visits in search of information about Faustino. At the end of the paper trail, he uncovers a single word intended to abridge Faustino’s entire existence: «expósito», «a marca dunha natureza particular e á parte» (Toro 2009: I40). The discovery that his grandfather was a foundling not only leaves the narrator with a truncated lineage but also unsettles his self-importance as a modern intellectual and his sense of belonging to a particular cultural milieu. Unable to uncover documented facts, he resorts to interviews, photographs and speculation. Through this process he learns that «[c]ada familia selecciona as lembranzas, as personaxes, para compor a súa historia» (2009: I47). In his particular family narrative — «historias de abandonos» (2009: 155) — relatives become characters, and literary fictions complement historical accounts and incomplete records. Instead of the history he hoped to write, de Toro's investigation results in a novel, a literary family history whose voids can only be filled by fiction and conjecture.

In order to accomplish this, Sete palabras draws on a breadth of sources from world literature, ranging widely from works by James Joyce, Franz Kafka, Claudio Rodríguez, Graham Green and Seamus Heaney to El Lazarillo de Tormes. Scholars such as Mariela Sánchez (20II) and Gómez-Montero (20I2) have analyzed the ways this particular novel brings autobiography and fiction to bear upon one another, both furthering and problematizing the memory work typical of de Toro's writing. Due to the narrator's professed tendency to «literaturiza[r] de máis» lived experience (Toro 2009: I40), or what Sánchez refers to as the novel's «plusvalía de literaturización» (20II: 4), Sete palabras can be read, I would argue, as much as a narrative about the creation of a personal history as of a literary one. Interestingly, in this complex literary lineage that de Toro traces, none of the novel's myriad intertextual references pertain to igth century Galician writing. Yet, Sete palabras — albeit perhaps unintentionally-revisits and rearticulates the anxiety of origin, illegitimacy and abandonment that were central themes in many of the Galician novels of the fin de siècle. The narrative prose written during the Rexurdimento not only has foundlings, orphans and/or illegitimate children as its protagonists, but 
has also seen its own role in the formation of a national literary canon largely ignored, and as such delegitimized.

As shown below, de Toro's novel provides a context in which to consider the obstinacy of illegitimacy as a part of Galician identity and literary history at a time when many scholars' concerns center precisely on questions of legitimacy. Through a personal search for origins, Sete palabras parallels the more collective struggles to locate and define galeguidade in which literary historians and other critics are currently engaged. The relationship between illegitimacy as a theme in fiction and anxiety around national literary identity formation has been studied previously in the novel of the Rexurdimento (Barreto 20ria), and in the narrative of Carvalho Calero in the r950s and ig8os (Miguélez-Carballeira 20I3: I53-166). In those works, issues of gender, class, history, modernity, language and sexuality are inextricably linked. Unlike the novels analyzed by Helena Miguélez-Carballeira, A xente da Barreira (I95I) and Scórpio (1987), in which illegitimacy is idealized and the bastard child is celebrated «as uncanny and superior, a creature of the threshold, effortlessly progressing from precocious poetic genius to national martyr by virtue of his clever avoidance of traditional societal —and sexual— laws» (2013: I6I), in de Toro's work, a seemingly complete identity begins to unravel because of the discovery of a foundling in the family tree. Through his writing, de Toro signals several of the fissures in national identity as well as omissions from its history — both social and literary — while accepting these exclusions as a potential source of alternative histories and identities. The particular history of foundlings alluded to in Sete palabras harks back to a silenced history and continues in a long novelistic tradition within Galicia, even if those literary origins are repressed or unrecognized by the author himself.

\section{FOUNDLINGS IN THE 19TH CENTURY}

The narrator/author's quest traverses many of the topoi of Galician identity: territory, language, emigration, and the igth century. The writer's journey leads him from present-day Santiago de Compostela to Zamora and Cuba, and back as far as the i80os. These spaces and times, when read metaphorically, represent the territorial and temporal limits of modern Galician identity: the linguistic/national border, the experience of emigration, and the Rexurdimento respectively. Although fiction allows the narrator to fill some of the gaps in his 
personal story, Sete palabras, as Gómez-Montero points out, also grapples with «dos aspectos muy específicos de la memoria social largamente reprimidos»: orphans and emigrants (2012: 57). While there is not much written on the history of orphans in Galicia, there is some documentation which does indicate that there is a rich, complex history of marginalized voices and lives to be explored.

Turning to a 1796 manuscript written by Marcos Marín, a professor of medicine in Santiago de Compostela, it is clear that the number of children abandoned or handed over to the foundling hospitals was considerable. In this document Marín writes: «El numero de niños que regularmente se depositan en esta Real Casa, es de ocho cientos á nueve cientos, de los quales las tres quartas partes perecen, y de esta la mitad a los ocho dias» [sic] (I796: n. pag.). He alleges that if the number of orphans in Ourense and A Coruña were to be added, «hallaremos un exceso tan grande, que horroriza a la naturaleza, y clama por su pronto remedio» (1796: n. pag.). Not only is the sizeable number of foundlings alarming, but so are the deplorable conditions to which they were exposed: they often arrived malnourished to the foundling hospital after long travels; later they would be sent to rural villages where they would be cared for by a poor family who, in exchange for housing the child, were paid a pittance. There, the foundlings would deal with not only the harsh conditions faced by the peasantry (the cold, lack of food, etc.), but were also quite often stigmatized and deemed vile. For example, Marín claims that when these children developed rashes, the adoptive families, fearing it was syphilis, would leave the children outdoors with the livestock. In his petition, he suggests that paying the families more might «convertir el horror, que tienen a los niños, en aquel amor paternal, que es carecteristico de la nación» [sic] (I796: n. pag.). This quote suggests that the expósito, in addition to facing physical challenges, was an outsider to the national family.

Throughout the igth century the foundling remained an object of social and political concern in Galicia. Ana María Rodríguez Martín (2008: 354-356), further to highlighting legal efforts in the i 850 s to build a foundling hospital in each provincial capital, has pointed out that, while the number of foundlings waned in the rest of Spain, Galicia's foundling hospitals continued to receive relatively higher numbers of children, a trend she attributes to a high birthrate and a greater frequency of births of illegitimate children, the most likely to be abandoned at an inclusa. Luz Román Portas's study of orphanages in Santiago during the second half of the i 800 s notes the trend of emigrants leaving large 
numbers of children for adoption. She states that on many occasions «se encomendaba a la Casa de Beneficiencia a los hijos, mientras los padres trataban de abrirse camino en tierras sudamericanas» (1989: 85), a finding that brings together two of the themes of Sete palabras — emigration and abandonmentwithin a historical context.

The invisibility of the inclusas, according to Rodríguez Martín, was owed to their being «ligados a la ilegitimidad, a la deshonra y a la pobreza», and as such «provocaban el rechazo social y el distanciamiento de las personas más destacadas de la ciudad» (2008: 382-3). A similar social invisibility was suffered by the foundlings themselves, who, like Faustino de Toro, suffered their «identidad difusa» which «corresponde con su falta de raíces: no contaban con padres, ni con apellidos propios, ni con patrimonio ni casa familiar» (Rodríguez Martín 2008: 380). Although these institutions were not well documented by historians or in the press, and did not keep detailed records through much of the period, orphans and foundlings did have a presence in literature. The first novel written and published in Galician was Marcial Valladares's Maxina ou a filla espúrea (I88I); however, despite her own illegitimacy, this spurious daughter bears a familiar resemblance to the many other protagonists of the Galician novel. Orphans, foundlings and illegitimate children populate the pages of many other novels, among them: Rosalía de Castro's La hija del mar (I859), Xesús Rodríguez’s A cruz de salgueiro (i899), Miguel Lugrís Freire's O penedo do crime (I889), Heraclio Pérez Placer's Prediución (I889), and Emilia Pardo Bazán’s Los pazos de Ulloa (I886), La madre naturaleza (I887), and Morriña ( 1889 ). The above-cited poem «Lo que envidia un expósito» by San Martín synthesizes the anxiety of many of the characters of these coetaneous novels: the longing for a personal identity and social legitimacy, symbolized by the possession of a last name.

\section{SETE PALABRAS AND THE NOVEL Of THE REXURDIMENTO}

Many foundlings had their baptismal surnames replaced with «Expósito» (Toro 2009: 350), or with the places they were found, such as «de Toro». Having always thought his toponymic last name was of Jewish origin, the realization it is simply a name given to foundlings produces a stir of emotions: «Esa explicación tan querida para o teu lado snob [...] Que se as túas listas de intelectuais e artistas xudeus. É, sénteste xudeu, un xudeu de carallo [...] Elitisimo, ver- 
dadeiramente iso é o que che atrae, ese elitismo cultural [...] Nin es xudeu nin descendes de xudeus, agora xa o sabes, o teu apelido vén dun hospiciano así vai deixando o conto de vez» (2009: 55). The myths around his identity provided, if nothing else, a sense of belonging to history and a literary tradition. Having these narratives pulled out from under him unsettles his position and leaves him feeling isolated.

This unsettling of identity requires the narrator and reader to reconsider the roles of place and language - two cardinal points of modern Galician identity - in the formation of the self. For example, it is particularly ironic (or perhaps appropriate) that the narrator/author, a Galician writer of comparable celebrity, should have a grandfather who comes from Zamora, a region considered geographically and linguistically a part of what has been termed «Galicia irredenta» (López Mira I998), belonging linguistically to the Galician-speaking world but administratively beyond its borders, and whose residents the narrator refers to as «[x]entes de fronteira, minorías abandonadas» (Toro 2009: I4I). This novelist considered by many to be one of the most representative of Galician letters has his roots in a bilingual territory, just as the contemporary Galician novel has its roots in Valladares's Maxina, subtitled «conto en galego e castelán». Sete palabras leaves behind Santiago —a place that is safely and comfortably Galician - for places where linguistic and political borders do not overlap and the subjects are delegitimized and abandoned, like a population of foundlings, forgotten as an inconvenient truth for a national and linguistically defined identity. Suso de Toro's anxiety about these border subjects has been shared by historians whose «acritical and achronic acceptance of the borders of the current territory of Galicia as the ultimate, undifferentiated borders of historical analysis», as Lourenzo Fernández Prieto warns, «can lead to errors just as grave as those resulting from a similarly unquestioning recourse to Spanish state borders» (2011: 26).

Questions of territory and language overlap with those of illegitimacy and abandonment in the treatment of the theme of emigration both in the novel as well as in history. It is Faustino's emigration that also leads to the shame that the narrator's father feels growing up as a fatherless child. The grandfather's disappearance also raises the uncomfortable question of whether he had a new family in Cuba, an idea that provokes another identity crisis in the narrator. At first he scoffs at the idea: «Daquela terías primos morenos, ou pretos. Escachas a rir neste cuarto de hotel habaneiro» (Toro 2009: 240). As the possibility becomes increasingly plausible, he worries about his own children and 
what he considers to be the shame of introducing them to a new set of illegitimate, poor and black relatives. The greatest challenge, however, is how this situation would undermine his own sense of identity as a modern, bourgeois European: «Aquí», he says in reference to Cuba, «non hai maneira de facer literatura europea, mecagoental» (2009: 252). Further on he states:

Recoñeces en ti ese temor a achegáreste á xente, a fundíreste nela. E tamén a vergoña anticipada de que realmente sexan parentes teus. Que has facer ti con esa parentela, dun tipo de humanidade tan distinto de ti, dun mundo tan distinto do teu. Aquí é todo moi literario, mais na túa vida diaria habíache resultar incómodo tratar con esas persoas. Hai en ti sutís repugnancias clasistas, non o negues (Toro, 2009: 253).

The threat of miscegenation creates a fear of impurity of blood, the idea that the family's racial and economic status could be delegitimized, making them less entitled to a European narrative of progress and privilege.

We know that the narrator is aware of the history and tales of Galician emigration by his trunk full of books on the topic. Although he is familiar with the narrative, when he draws close to the experience of emigration, he has to confront the lived reality of the emigrant. His sense of self is threatened and he feels ashamed and fearful that Galicianness, which he has imagined as solely European, might in fact not be, thereby undermining his status as a modern European intellectual.

Ultimately, once he has dismissed the possibility of any relation, he paints a more sympathetic view of this Cuban de Toro that resonates with his own sense of being the grandson of a foundling. He writes, «A inseguridade, a inestabilidade, a ansiedade que deben sentir os mulatos, divididos entre o desexo de asimilarse aos brancos á fin e o orgullo e a reivindicación dunha orixe negra. Mais sen poder ser verdadeiramente nin un nin outro, un impostor sempre» (2009: 262). Not having any genetic relation opens the possibility for a new sense of self-recognition in the other de Toro. The uncanny sense of detachment and belonging experienced by the narrator reflects the ways in which «from afar it is possible to see things up close, to reclaim them as one's own», as Mariela Méndez affirms in her analysis of similar themes of space, gender and identity in the poetry of María do Cebreiro Rábade Villar (20I4: 645).

This patrilineal history of « $[\mathrm{t}]$ odos eses homes» that he originally sought to write and which would weave together the history of the men of his family becomes a ghostly «camiño de ecos e sombras e vaste transformando coas más- 
caras dos outros, teu avó, teu tío, teu pai» (Toro 2009: 206). Despite his obsession with understanding and even taking on these men's identities, as the author continues to probe into this masculine past, questions of gender too arise, revealing yet another omission from the personal and collective histories. As the collection of documents, photos, and books continues to grow, he becomes aware that this patriarchal history and others are incomplete: «Recordas na túa equipaxe os libros sobre os emigrantes ás Américas e pensas que hai pouco escrito sobre as mulleres e os fillos que ficaban» (2009: 155). The project of creating a national narrative and limiting definitions of galeguidade has led to a sense of identity and a history marked, as Kirsty Hooper puts it, by «lagoas e ausencias» (2006a: 65), particularly those of women and their cultural production. Confronting his spurious origins, the narrator realizes that, rather than forfeiting the story he hoped to tell, it is simply a different one. Towards the end of his search and novel, the narrator wonders if it was really his grandmother Valentina «quen che encargou esta busca e non teu pai, como pensabas? Daquela non foi a ferida da orfandade do teu pai, foi o amor da Valentina?» (2009: 295). The narrator realizes that another story is possible, one in which his grandmother «[p] ode ser vista como unha heroína abandonada» (2009: 295). Although this heroine remains at the margins, it seems relevant that de Toro's patriarchal novel does recognize the sexism that has rendered the feminine invisible within discussions of national literary identity, an idea that reflects those of critics such as Hooper (2006b) and Miguélez-Carballeira (2013).

Establishing an origin story upon a single patriarch intended to act as the foundation of the identity of a modern, bourgeois Galician man quickly reveals itself to be an impossible task. If rethinking history, as Rábade Villar suggests, «significa rescatar tamén as outras historias que existiron pero que non se impuxeron» (2012: 4), in Sete palabras, writing the history of fathers and sons and of the canonized author prompts the need for alternative histories of abandoned women, orphans, foundlings and emigrants. Like the narrator, de Toro's readers must accept the fact that origins are incomplete, multiple and impure. The search for Galician origins — as exemplified by de Toro's noveloften leads authors, critics and literary historians back to the second half of the igth century. Interestingly, however, as stated earlier, de Toro's narrator seems to ignore any direct connection to the Galician literature of this period, despite the thematic and ideological commonalities. Just as he is unwilling to accept Faustino's reduction to the single word «expósito», de Toro, like many 
scholars, continues a trend in Galician letters of omitting the igth century novel as part of its literary history.

During the Rexurdimento, «the renewal of the Galician language, literature, and other forms of artistic activity were part of the political project to reclaim a national status for Galicia» (Figueroa 20 I : 40). Historians and literary critics are wont to remember the period as one in which intellectuals sought to give shape, visibility and legitimacy to a history and culture that had been expunged by Spanish nationalism. Galician literature, as Xoán González-Millán (1994; 1998) has argued, became implicated in and inseparable from this legitimizing political project given the relative weakness of other social discourses, a notion echoed by Antón Figueroa (2011: 40) in his recognition that this political process went hand in hand with the sentiments expressed through Galician poetry. As such, the history of Galician nationalism is inseparable from a history of Galician literature and, like de Toro's personal narrative, «mestur[a] o vivido co soñado ou imaxinado» (Toro 2009: 20).

Extolled as the period of creation of a modern Galician self-awareness, the Rexurdimento is less remembered for the lack of political consensus, linguistic plurality and ideological ambiguity by which it was characterized. At this purportedly singular originary moment in the igth century, we find, as Figueroa reminds us, that «A literatura rexorde, ou nace se quere, vinculada a unha heterodoxia política e tamén en certo modo como unha heterodoxia literaria dentro do campo español» (200I: I 4). More recently, Rábade Villar has underlined the fact that «[d]ende o Rexurdimento, a literatura galega enfrentouse ao problema da fractura social e da descontinuidade histórica e nalgúns casos converteu, paradoxalmente, estas condicións en estímulos para a súa construción e supervivencia» (20I1: 34). Discontinuities and losses, as she illustrates in the work of Rosalía de Castro - herself the iconic illegitimate child of Galician lettershave the potential to become catalysts for a literary production imbued with deep political resonances. So it is the case with de Toro's narrator whose introspection reveals: «O que se che revelaba era un baleiro que levabas dentro e nin sequera o sabías, e en descubríndoo sentías alegría» (2009: ı8).

Yet, while many writers of the Rexurdimento acknowledged these fractures, critics - motivated by an obsession with purity and fear of «a fragmentación (identificada co dialectalismo) e a contaminación (identificada coa presión do castelán)» (Rábade Villar 20ıг: 40)— have tended to readings that favor a linguistic national project. However, continuing to read the igth century in relation to this project is proving to be an unsustainable practice. 
Rábade Villar (20II) has also shown that the poetry of the Rexurdimento did not only help to legitimize a Galician political project but also offered a resistance to some of the dominant and limiting forces within the galeguista movement. I would argue that the criterio filolóxico (linguistic criterion) and its fixation on linguistic purity has been responsible for the exclusion, marginalization and underestimation of Galician prose of the Rexurdimento, as these works are almost by definition works that draw heavily on Castilianisms, dialects, and non-standardized language choices, a claim made in earlier studies of sexuality and emigration in the igth-century novel (Barreto 20IIa; Barreto n.d.).

During the Rexurdimento, Galician novelists in both Castilian and Galician faced the challenges of creating a regional literature in prose without many local models, the latter undertaking the doubly arduous task of creating in a language that had developed an air of rustic humility and grown unaccustomed to appearing in print. Whereas writers in verse could seek particularly Galician modes of expression in the cantigas and poetry of the Middle Ages, Galician novelists had little beyond the folktale, a genre well cultivated during the Rexurdimento. Owing to this predicament, González-Millán claimed Maxina ou a filla espúrea was a landmark in modern literary history whose «relevancia en el contexto del incipiente sistema literario gallego de la época sería igual o superior a la del poemario rosaliano» (2004: 52). Despite the relevance of the Rexurdimento novel, the conditions alongside which the novel thrived throughout Europe and the Americas — an urban bourgeoisie, an independent nation-state and an imperial language- were unevenly available to writers within the Galician context. For these reasons, the Galician novel emerged in the fin de siècle as a genre of secondary importance and enjoyed limited attention from readers and critics, both then and now.

Although Sete palabras was written nearly a century and a half later, the literary obsession with tracing origins and grappling with discontinuities persists. This may not be surprising given that many of the conditions under which the Rexurdimento novel emerged endure today: the «symbolic codification» of Galician identity «from within Galician society itself» still rests heavily on the literary field and the act of «reading (and writing too) in Galician is not only a political practice, but also a subversive one because of its lack of role models» (Vilavedra 2008: I88, 226). Obviously the preoccupation with origins is not unique to Galicia, nor is de Toro alone in this search for origins and legitimacy within Galicia. As Hooper has shown, contemporary women writers too have been struggling with issues of genealogy, turning to literature 
«where those myths of origin can be most comprehensively rewritten» (2006b: 45). Sexual identity, emigration and family history are entwined in Mario Regueira's Outono aquí (20I2), and in the recent Galician film Crebinsky (20II) orphans return to their place of origin. These collective and individual searches for origins convert the rupture and silence that characterize this history into catalysts for creation.

Despite being in good company, for the individual, the process of recognizing that one's identity is founded upon omissions and lack is a difficult one. As we see in Sete palabras, the sense of self as a modern, middle-class intellectual of importance is constantly threatened by a history of abandonment which forces him to reconsider his sense of belonging to a particular language, territory, class and cultural context. Exposing the crevices in the foundational myths upon which identity has been built will involve exposing illegitimacy, shifting authority away from the center and toward those who have been pushed to the margins: from the masculine towards the feminine, from center to periphery, from home to abroad, from purity to hybridity.

\section{CONCLUSIONS: FROM LEGITIMACY TOWARDS BELONGING}

«Any national legitimization project», Figueroa writes, «whether completely or only partially successful, is a social process that commits an entire group to the search for internal and external recognition» (20Ir: 40). Similarly, Fernández Prieto claims that historians of Galicia are «condemned to become involved in the political and social struggles over the legitimacy of their objects of study» (20I1: 25). These concerns have extended to the field of Galician Studies in recent years, as critics and writers have had to ineluctably weigh in, however implicit or explicitly, on the ontological question of who and what is Galician. The legitimacy of the field and cultural identity has rested heavily on language and literature. This philologization of culture has led to what Vilavedra terms a defensiveness of linguistic and literary discourse, a reification that «exerts a kind of tacit protectionism on the different manifestations of that common heritage that is language» (2008: 22 I-222). These scholars' concerns were voiced within two years of the publication of Sete palabras. Since then some of that defensiveness seems to be subsiding with the increased recognition of Galicia within academe (the increased visibility of the field within the Modern Language Association, numerous international conferences, the launching of new jour- 
nals, publications in languages other than Galician, etc.). Similar to my previous argument that cinema has permitted hybridized notions of galeguidade to be performed (Barreto 20IIb), a move away from discourses centered solely on «legitimacy», «recognition» and «heritage»—a logic and rhetoric steeped in patriarchy - will perhaps open up more space for alternative, dissenting and diverse voices.

Since the Rexurdimento, writers and historians have invested tremendously in projects seeking to limit Galicia to a homogeneous, distinct and discrete territorial and linguistic entity. Yet, remarkably, Galicia continues to elude any limiting discourses and draws our attention to the fact there exist multiple Galicias. Time and again we find ourselves having to adjectivize a number of places, peoples and practices that are undeniably Galician but that do not conform to these rigid territorial and linguistic boundaries, such as Galicia estremeira, Galicia emigrante and Galicia castelanizada.

Similarly, it is worth considering the existence of a Galicia espurea. This spurious Galicia is that which refuses to ignore the discontinuities, traumas and absences in its own history. The voice of this Galicia is perhaps loudest in the prose of the Rexurdimento, a period in which «a perda converteuse nun dos motores da produción cultural, e a literatura nun dos seus principais de representación histórica» (Rábade Villar 20II: II), but, as illustrated by Sete palabras, it continues to haunt the present. The history of the Galician novel has been a discontinuous one (March 2008), leading to anxiety about what it means to write a Galician novel or to situate oneself within a national novelistic tradition. Rather than fear a lack of origins, the modern writer and critic can see him or herself as part of a long and strong literary trajectory that is bound precisely by questioning the dominant myths of national origin. Once we move beyond genealogies and origins, we can trace what Méndez would call «alternative mappings of belonging», discourses that «construct a sense of belonging via dispossession, disowning, distance» (20I4: 648).

Literature's efficacy in legitimizing the nation has depended upon its ability to create a sense of what Benedict Anderson would call «community» (I99I) or Doris Sommer, «intimacy» (I99I). Nineteenth-century writers were able to accomplish this through a wide number of metaphors, particularly those of the nation as home or as family. Making nation synonymous with home could mean, by extension, that the members were like a family bound not only to a shared space and language but also to each other through a set of affective, economic and biological bonds. Although times have changed and the literary 
and national projects have evolved, in the case of Galicia, writers and critics still strive to legitimize a particular national identity, and inescapably discover that their familial and national genealogy is incomplete, exposing a Galicia that shares the plight of a spurious child. This Galicia, which has been silenced and kept from view, is a persistent source of illegitimacy that haunts the literary imaginary and that threatens to challenge the dominant myths of galeguidade. Yet, if embraced and accepted, it can become a source of creativity and, contradictory though it may seem, provide an alternative sense of belonging to Galicia that would transcend territory and language.

\section{WORKS CITED}

Anderson, Benedict (1991). Imagined Communities: Reflections on the Origin and Spread of Nationalism. New York: Verso.

BARRETo, Danny (20Ira). «A promiscuidade sexual, lingüística e rexional da novela galega do século XIX: un estudo d'A cruz de salgueiro de Xesús Rodríguez López». Galicia $21, \mathrm{C}, 3^{-18}$.

Barreto, Danny (20I b). «Ir de morto, ir de vivo: Galicians in a State of Living Death». Journal of Spanish Cultural Studies, 12.4, 385-399.

Barreto, Danny (n. d.). «Sen pátrea nin lareira’: los espacios nacionales y domésticos en la novela transatlántica ¡A Besta! de Xan de Masma». Galician Review [forthcoming].

Fernández Prieto, Lourenzo (20II). «Interpreting Galician History: The Recent Constructions of an Unknown Past». Kirsty Hooper; Manuel Puga Moruxa (eds.). Contemporary Galician Cultural Studies: Between the Local and the Global. New York: MLA, 24-39.

Figueroa, Antón (200I). Nación, literatura, identidade. Vigo: Xerais.

Figueroa, Antón (20II). «National Literature and the Literary Field». Kirsty Hooper; Manuel Puga Moruxa (ed.). Contemporary Galician Cultural Studies: Between the Local and the Global. New York: MLA, 40-53.

Gómez-Montero, Javier (20I2). «Del mito a la anamnesis. Subconsciente urbano y memoria histórica en Trece badaladas y Home sen nome de Suso de Toro (con un apunte sobre la dificultad de la reconstrucción memorialística en Sete palabras)». Sadi Lakhdari (coord.). Voces de Galicia: Manuel Rivas y Suso de Toro. Paris: Indigo; Côté-femmes Éditions, 42-66.

GonZÁlez-Millán, Xoán (1994). «Do nacionalismo literario a unha literatura nacional. Hipóteses de traballo para un estudio institucional da literatura galega». Anuario de Estudos Literarios Gallegos, 67-8I. 
González-Millán, Xoán (i998). «O criterio filolóxico e a configuración dunha literatura nacional: achegas a un novo marco de reflexión». Cadernos da Lingua, I7, $5-24$.

González-Millán, Xoán (2004). «E. Pardo Bazán y su imagen del "Rexurdimento" cultural gallego en la Revista de Galicia». La Tribuna, 2, 35-62.

Hooper, Kirsty (2006a). «Novas cartografías nos estudos galegos: nacionalismo literario, literatura nacional, lecturas posnacionais». Anuario Grial de Estudos Literarios Galegos 2005, 64-73.

Hooper, Kirsty (2006b). «Alternative Genealogies?: History and the Dilemma of "Origin” in Two Recent Novels by Galician Women». Arizona Journal of Hispanic Cultural Studies, I0, 45-58.

López Mira, Álvaro Xosé (i998). A Galicia irredenta. Vigo: Xerais.

March, Kathleen (2008). «The Galician Novel». Marta E. Altisent (ed.). A Companion to the Twentieth-Century Spanish Novel. Woodbridge: Tamesis, 235-246.

Marín, Marcos (1796). Plan presentado a los señores visitadores de esta Real Casa... con el fin de mejorar la suerte de los niños expósitos que en su Real Inclusa se depositan. Manuscript. Biblioteca Xeral: Santiago de Compostela.

Méndez, Mariela E. (20I4). «Alternative Mappings of Belonging: Non son de aquí by María do Cebreiro and Rasgado by Lila Zemborain». Bulletin of Hispanic Studies, 9i.6, $637-657$.

Miguélez-Carballeira, Helena (2013). Galicia, a Sentimental Nation: Gender, Culture and Politics. Cardiff: U. of Wales P.

Moreiras-Menor, Cristina (20II). «Narrativa gallega contemporánea y memoria cultural». Palmar Álvarez-Blanco; Toni Dorca (coord.). Contornos de la narrativa española actual (2000-2010). Un diálogo entre creadores y críticos. Madrid: Iberoamericana, I5I-I6I.

Rábade Villar, María do Cebreiro (20II). Fogar impronunciable: poesía e pantasma. Vigo: Galaxia.

Rábade Villar, María do Cebreiro (20I2). «Entre a norma e a excepción». Galicia 2I, D, 3-4.

Rodríguez Martín, Ana María (2008). «El destino de los niños de la Inclusa de Pontevedra, I872-1903». Cuadernos de Estudios Gallegos, 55.121, 353-388.

Román Portas, Luz (I989). La asistencia social en Galicia: El Hospicio de Pobres de Santiago de Compostela. ( I860-1900). A Coruña: Diputación Provincial de A Coruña.

Richardson, Nathan E. (2002). «Of Cows and Melancholics: Regional Cities and Countries on the Global Map». Postmodern Paletos: Immigration, Democracy and Globalization in Spanish Narrative and Film, 1950-2000. Lewisburg: Bucknell UP, I72-206.

Romero, Eugenia (2012). Contemporary Galician Culture in a Global Context: Movable Identities. Lanham: Lexington Books. 
San Martín, Jacobo ([ı880] I999). «Lo que envidia un expósito». Revista de Galicia, i8 March. Ana María Freire López (ed.). La Revista de Galicia de Emilia Pardo Bazán ( I880). A Coruña: Fundación Barrié de la Maza.

SÁnchez, Mariela (2009). «Hombre sin nombre, memoria sin identidad: transmisión oral de la experiencia bélica en la novela de Suso de Toro». José Amícola (dir.). Actas del VII Congreso Internacional Orbis Tertius de Teoría y Crítica Literaria. [Online] [I5 November 20I4]. <http://www.memoria.fahce.unlp.edu.ar/trab_eventos/ ev.36rz/ev.36riz.pdf $>$.

SÁnchez, Mariela (20II). «Una vida en siete palabras: Suso de Toro y la memoria que (se) resiste». II Congreso Internacional de Literatura y Cultura Españolas Contemporáneas, 3 al 5 de octubre de 20II. [Online] [I5 November 20I4]. <http://www. memoria.fahce.unlp.edu.ar/trab_eventos/ev.28ı I/ev.28ıı.pdf>.

Sommer, Doris (199i). Foundational Fictions: The National Romance of Latin America. Berkeley: U of California P.

Toro, Suso de (2009). Sete palabras. Vigo: Xerais.

Vilavedra, Dolores (2008). «The Galician Reader: A Future Project?». J. Manuel Barbeito; Jaime Feijóo; Antón Figueroa; Jorge Sacido (ed.). National Identities and European Literatures. New York: Peter Lang, 221-232.

VilaVEDRA, Dolores (20I0). «Political Autonomy and Literary Institutionalization in Galicia». Luis Martín-Estudillo; Nicholas Spadaccini (ed.). New Spain, New Literatures. Nashville: Vanderbilt UP, II7-I33. 